HELMINTHOLOGIA, 58, 3: 233 - 247, 2021

\title{
Abundance and annual distribution of freshwater snails and some trematode cercariae at Damietta Governorate, Egypt
}

\author{
M. E. EL-ZEINY, A. M. GHONEIM*, O. A. ABU SAMAK, A. A. KHIDR
}

Zoology Department, Faculty of Science, Damietta University, New Damietta 34517, Egypt,

E-mail: mohammedelzeiny@du.edu.eg, *am_ghoneim@du.edu.eg, olaabusamak@du.edu.eg, Akhidr@du.edu.eg

\section{Article info}

Received June 3, 2020

Accepted May 12, 2021

\section{Summary}

In addition to being a good food source, freshwater snails are considered one of the positively and negatively influencing invertebrates on the environment. Several biotic and abiotic factors are thought to affect the distribution and the dynamics of these snails. Freshwater snails are the most dominant and conspicuous individuals of the freshwater biota in Damietta Governorate. In this study, freshwater snails were collected monthly from 5 geographically and environmentally different sites at Damietta Governorate at the north of Egypt during June 2017-May 2018. Seven snail species; Lanistes carinatus, Lanistes varicus, Pila wernei, Segmentorbis angustus, Melanoides tuberculata, Biomphalaria alexandrina, and Gabbiella senoriansis, were identified. Lanistes carinatus was the most abundant species (56.4\%) in the collection sites. Besides, Al-Inaniyyah village had the highest snail species abundance and variety. The abundance of the most recorded species varied seasonally; the highest abundance was recorded during summer while the lowest was during winter. The abundance of some snail species correlated positively or negatively with some physico-chemical parameters; water temperature, dissolved oxygen, conductivity, total dissolved salts, and electrical conductivity. Two types of trematode cercariae; gymnocephalus cercariae and xiphidiocercariae, were harvested from Lanistes carinatus. The highest prevalence of both cercarial types was detected during summer. The correlation between the prevalence of both cercarial types and the physicochemical parameters were determined. Xiphidiocercariae were the most predominant cercarial type in Damietta Governorate. Our findings suggest that the invasion of some freshwater snails is likely to be the cause of the low prevalence or complete absence of some medically important intermediate snail hosts. We recommend further characterization of the distribution of freshwater snails and the interrelationships among them in Egypt, and suggest a controlled use of selected snail species to combat their medically important analogues.

Keywords: Snails; cercariae; abundance; seasonal; physico-chemical; Lanistes

\section{Introduction}

Freshwater snails have vital roles in life where they represent a food source, contribute in recycling nutrients, and serve as bioindicators of metals in the ecosystem (Elder \& Collin, 1991).
Moreover, snails are considered one of the influencing invertebrates and they have economic importance (Sharma et al., 2013). They help in maintaining good water quality for other benthic aquatic invertebrates by consuming harmful algal blooms, detritus, and organic matter (Ukam et al., 2018). However, some snail species

\footnotetext{
$\overline{\text { * }- \text { corresponding author }}$
} 
can cause economic losses, for example the invasive golden apple snails (Pomacea canaliculata) have caused a significant ruin to the newly planted rice fields (Joshi et al., 2001; Greene, 2008). Besides, several species of the apple snails (Pomacea canaliculata and Pila polita) may also serve as intermediate hosts for larval nematodes, e.g. Angiostrongylus cantonensis that causes eosinophilic meningitis in human (Tesana et al., 2008 \& Chen et al., 2011).

Most species of snails act as intermediate hosts, in which several developing larval stages such as sporocysts, rediae, and cercariae are formed (Elsheikha \& Elshazly, 2008). These snails are infected by the penetrating miriacidia or by ingesting the eggs (Bdir \& Adwan, 2011). Larvae of trematodes (cercariae) emerge from the snail tissue and might find the suitable secondary intermediate host or definitive host (Bdir \& Adwan, 2011; Chantima et al., 2018). The genera of Biomphalaria, Bulinus, Lymnaea, Melanoides, Pomacea, and Asolene are important intermediate hosts for the trematode parasites Schistosoma, Stomylotrema, Echinochasmus, Phaneropsolus, and Fasciola (Besprozvannykh et al., 2013; Dida et al., 2014; Pinto et al., 2015; Dellagnola et al., 2019). Therefore, freshwater snails perform significant roles in the human and veterinary health (Okafor \& Ngang, 2004).

Snail control methods are, thus, a requisite in order to reduce the parasites and the diseases transmitted by them (Madsen \& Hung, 2014). Several biological control programs used the snail
Melanoides tuberculatus as a competitor of the snail intermediate hosts of Schistosoma (Pointier \& Jourdane, 2000). Furthermore, the freshwater apple snail Lanistes varicus has been considered for many years as effective biological control against snail intermediate hosts of schistosomiasis (Pointier \& Jourdane, 2000; Anto \& Bimi, 2017).

Environmental factors are known to affect the distribution patterns, life cycles, and population dynamics of snails (Rollinson et al., 2001). There are several biotic and abiotic factors that affect the distribution and the ecology of snails. The abiotic factors include physical factors such as water current, temperature, turbidity, transparency, and distribution of suspended solids and chemical factors such as ion concentration and dissolved gases in water. The biotic factors include availability of food, competition, and predator-prey interactions (Ofoezie, 1999). Moreover, the aquatic macrophytes (vegetation) have been shown to play vital roles in the distribution of snails in different parts of Africa (Ofoezie, 1999). One of the two River Nile branches in Egypt, Damietta Nile Branch, runs for about $242 \mathrm{~km}$ from Delta Barrage to the Mediterranean Sea. This branch serves as the major source of water for municipal, industrial, and agricultural uses and enriches many governorates such as El-Qalubia, El-Gharbyia, El-Dakahlyia, and Damietta (El-Amier et al., 2015). Unfortunately, freshwater ecosystem of Damietta governorate receives polluted waters from different sources including industrial, agricultural and urban sewage (Badr

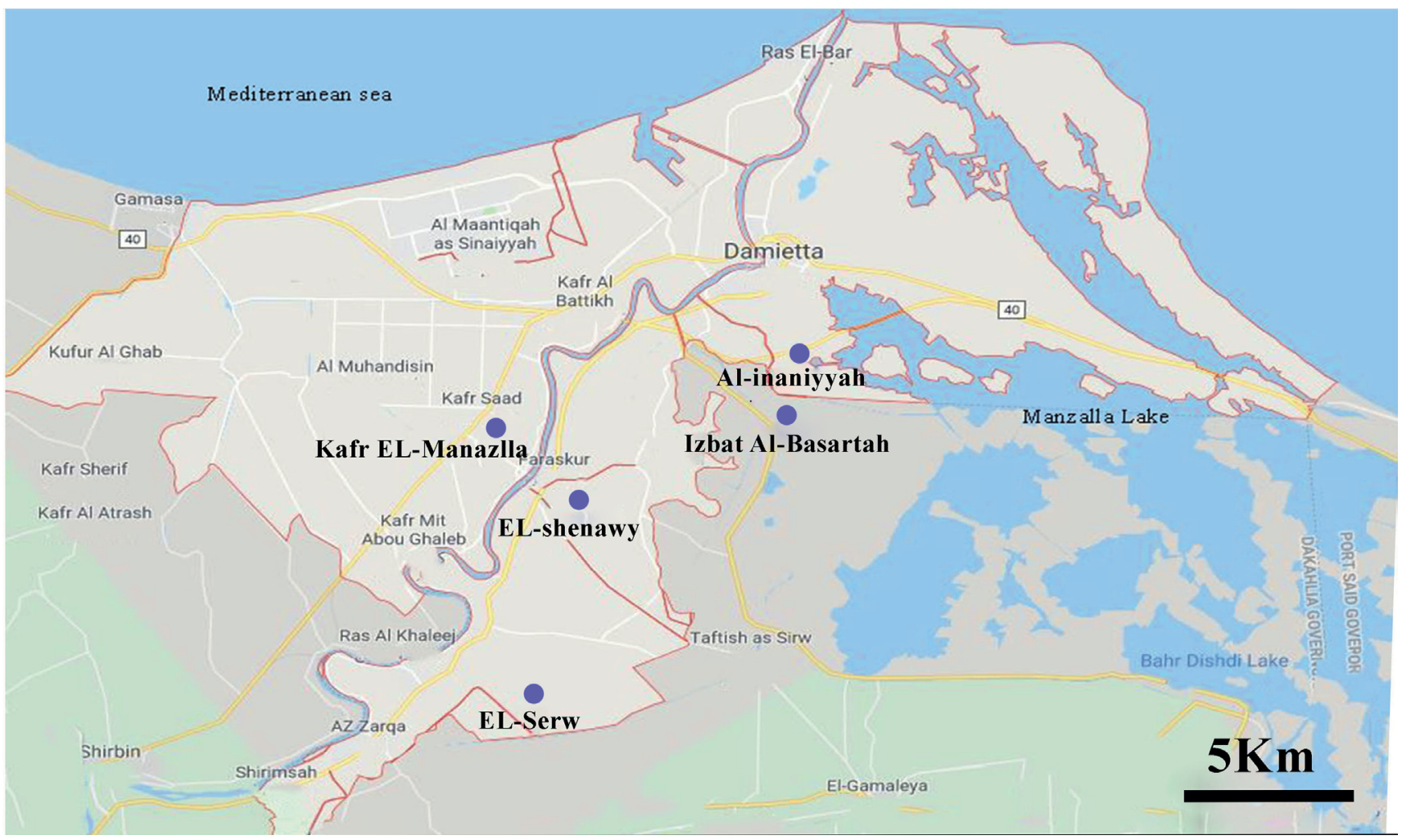

Fig. 1. Location map showing study area in Damietta Governorate. Five sites were selected for this study; Al-Inaniyyah village; Izbat Al-Basartah village; EL-Shenawy village; EL-Serw and Kafr EL-Manazlla village. 
et al., 2013; El-Amier et al., 2015). Freshwater snails were the most dominant and evident individuals of the freshwater biota at different regions in Damietta Governorate; Bostan, Adlyia, Damietta, El-kashf, and El-Serw drainage stations (Mahmoud \& Sayed 2018).

Surveying snails, especially the species involved as intermediate hosts of digenetic trematodes, are needed for disease control (Rozendaal, 1997). It is crucial to know the habitat, ecological factors, and distribution of the freshwater snails especially the medically and economically important species. Unfortunately, few studies addressed the ecology and population dynamics of the freshwater snails in Egypt (Hussein et al., 2011; Marie et al., 2015; El-deeb et al., 2017; Mahmoud \& Sayed 2018). Because of this and the unique freshwater ecosystem of Damietta governorate, the present study aimed to (1) survey the freshwater snails in selected sites at Damietta governorate, (2) determine the abundance of these snails and the seasonal changes in their abundance, (3) investigate whether there is a correlation between the abundance of these snails and some physicochemical parameters, and (4) address the seasonal changes in the snails' cercarial contents and investigate whether there is a correlation between their prevalence and some physicochemical parameters.

\section{Materials and Methods}

Study area

The study area covered 5 sites at Damietta Governorate, Egypt (Fig. 1). These sites were Al-Inaniyyah village, Izbat Al-Basartah village, EL-Shenawy village, EL-Serw, and Kafr EL-Manazlla village. Selection of these sites depended on the differences in water source and the human and domestic animal activities. The water sources were drainage canal at Al-Inaniyyah village, irrigation canal at Izbat Al-Basartah, EL-Shenawy village, and EL-Serw, and the Nile's Damietta Branch at Kafr EL-Manazlla village. Al-Inaniyyah village is located at the northern-east of Damietta Governorate; at Manzala Lake borders between 31.39"N and 31.81 "E. Izbat Al-Basartah is located at the northern-east of Damietta Governorate between Al-Inaniyyah and Izbat Al-Nahdah villages; between 31.38 "N and 31.79 "E. EL-Shenawy village is located at the southern-east of Damietta Governorate at the east of Nile's Damietta Branch; between 31.44"N and 31.29"E. ELSerw is located at the south of Damietta Governorate at the east of the Nile's Damietta Branch; between 31.20"N and 31.63"E. Kafr EL-Manazlla village is located at the west of Damietta Governorate between 31.35 "N and $31.68 " \mathrm{E}$.

\section{Snail sampling and cercariae harvesting}

Snails were collected monthly from June 2017 to May 2018 by a fishing net or by hand picking from rocks and plants. The collected snails (Fig. 2) were brought to the laboratory in labeled plastic bottles for identification and nomenclature. Identification of snails depended on the shape and size of shell, aperture shape, and number of whorls (Brown, 1994; Lotfy \& Lotfy, 2015). After separation of specimens into species, they were then counted, and their abundance was determined.

Cercariae were harvested by exposing the snails to a strong (a)

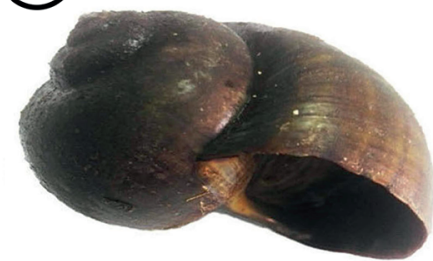

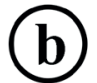

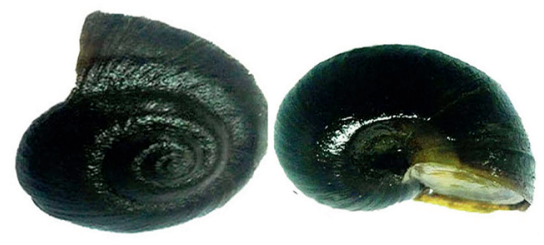

(c)

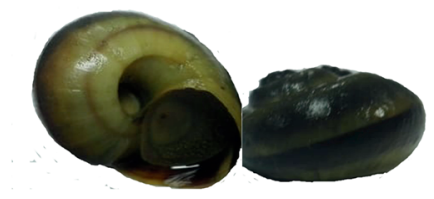

$1 \mathrm{~cm}$ (d)

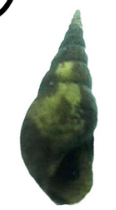

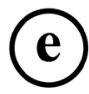

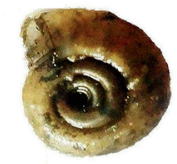

(f)

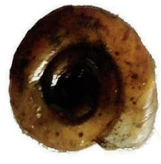

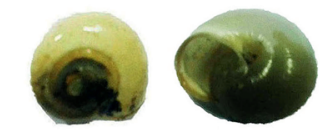

(g)

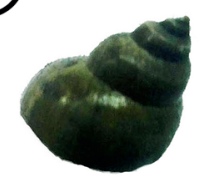

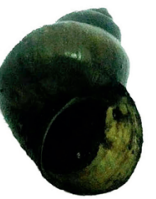

$4 \mathrm{~mm}$

Fig. 2. Snail species collected from different sites in Damietta Governorate. a: Pila wernei; b: Lanistes carinatus; c: Lanistes varicus; d: Gabbiella senoriansis; e: Biomphalaria alexandrina; f: Segmentorbis angustus, and g: Melanoides tuberculata. (Scale bar: $1 \mathrm{~cm}$ and $4 \mathrm{~mm}$ ) 
artificial illumination for a period of $4-6$ hours. The collected cercariae were transferred to Petri dishes for identification and their prevalence was determined. According to Luhe (1909), morphological identification of cercariae is based on the number and position of body suckers, the shape and relative dimensions of the cercarial tail, and the presence or absence of various specialized tegumental structures like stylet, spiny collar, and sensory papillae types. The harvested cercariae were picked up and transferred to $1.5 \mathrm{ml}$ tube containing $70 \%$ ethanol for fixation for 2 hours. The fixed cercariae were stained using Mayer's Paracarmine.

Collection of water samples and physicochemical analysis

Samples of freshwater were collected monthly from the five sites under study using tightly-stoppered bottles. Water temperature $(T)$ was recorded with a Celsius thermometer, and the total dissolved salts (TDS) and water conductivity (EC) were measured monthly using YSI Model 33 S-C-T Meter (Yellow springs). pH of water samples was measured monthly electrometrically in the same sampling day using an Orion electrode standardized with $\mathrm{pH}$ buffer kit. Dissolved oxygen (DO) was measured monthly according to Winkler's method.

\section{Statistical analysis}

Snails diversity was assessed by calculating some general diversity indices, like Shannon diversity index (H), evenness index (E), and richness index (d) following Hossain et al. (2017). The significance of seasonal variations and the fluctuations of snail abundance were determined by ANOVA test using SPSS package (version $25)$. The significance difference was set at $p \leq 0.05$. Pearson's correlation coefficient was used to assess the correlation between both of the snail abundance and cercariae prevalence and the physicochemical parameters. Canonical Correspondence Analysis (CCA) was performed by CANOCO (version 4.5) to assess the association of snail species with the environmental factors. Monte Carlo test was used to evaluate the significance of the environmental variables through 499 permutations.

\section{Results}

Abundance of snails and the harvested cercariae

A total of 1524 snails (Table 1) were collected from the study area and they were classified according to Brown (1994) into seven species (Fig. 2). These species are Lanistes carinatus (Olivier, 1804), Lanistes varicus (Müller, 1774), Pila wernei (Philippi, 1851), Segmentorbis angustus (Jickeli, 1874), Melanoides tuberculata (Müller, 1774), Biomphalaria alexandrina (Ehrenberg, 1831), and Gabbiella senoriansis (Küster, 1852). The freshwater snails Lanistes carinatus and $L$. varicus existed in all the 5 sites of study. But, the snail species Segmentorbis angustus existed in 4 sites and was absent from Kafr EL-Manazlla village. The snails Pila wernei, Melanoides tuberculata, and Gabbiella senoriansis were collected only from Al-Inaniyyah village and Izbat Al-Basartah village. The snail Biomphalaria alexandrina was collected from AlInaniyyah village only. Lanistes carinatus was the highest snail in occurrence $(56.4 \%)$. The Shannon diversity index for snails was high at Al-Inaniyyah village and low at Kafr EL-Manazlla village, while the evenness index was high at EL-Serw and low at Izbat AlBasartah village (Table 2). One-way ANOVA revealed no significant differences in the values of Shannon and evenness indices between different sites $(P=0.086$ and $P=0.64$, respectively). The highest value of richness was detected at Al-Inaniyyah village, while the lowest value was recorded at Kafr EL-Manazlla village (Table 2). One-way ANOVA revealed a significant difference in the value of richness between different sites $(F=7.46$ and $P=0.002)$. Because of the high abundance of Lanistes carinatus, this snail was selected for cercariae harvesting. Cercariae harvested from this snail were identified into two types; gymnocephalus cercariae and xiphidiocercariae based on light microscopy of stained cercariae (Fig. 3), and the identification was confirmed by other tools (not included here). The body of the harvested gymnocephalus cercaria is ovate in shape, $165 \mu \mathrm{m}$ long and 120 $\mu \mathrm{m}$ wide. Tail is $170 \mu \mathrm{m}$ long, $30 \mu \mathrm{m}$ wide, without fin-folds and with some sensory papillae. The oral sucker is sub-terminal and $26 \mu \mathrm{m}$ in diameter. The ventral sucker is well developed and larger than the oral sucker. The digestive system and cystogenous gland were observed (Fig. 3). While, the body of harvested xiphidiocercaria is cylindrical in shape, $72 \mu \mathrm{m}$ long and $40 \mu \mathrm{m}$ wide. Tail is 75 $\mu \mathrm{m}$ long, $13 \mu \mathrm{m}$ wide and without fin-folds. The oral sucker is sub-terminal and armed with stylet. The diameter of the ventral sucker is almost equal to that of the oral sucker. The prevalence of these two types of cercariae was determined (Table 1). The gymnocephalus cercariae were recorded only at Al-Inaniyyah and Kafr EL-Manazlla villages. While, the xiphidiocercariae existed in all the 5 study and their total prevalence $(4.5 \%)$ was higher than that of the gymnocephalus cercariae $(2.3 \%)$. The drainage canal of Al-Inaniyyah village had the highest prevalence of xiphidiocercariae $(6 \%)$, while the Nile's Damietta Branch at Kafr EL-Manazlla village had the highest prevalence of gymnocephalus cercariae $(9.52 \%)$.

Relationship between the seasonal changes and the abundance of snail species and cercarial types

The seasonal changes of snail abundance and cercaria prevalence are shown in Table 3. All the snails collected during the present investigation existed during spring. Most snails existed during summer except for the snail Segmentorbis angustus. Two snails, Melanoides tuberculata and Biomphalaria alexandrina, disappeared during winter and autumn. Statistical analysis revealed a significant difference between the different seasons in the abundance of the snails Lanistes carinatus, Lanistes varicus, Pila wernei, and Segmentorbis angustus $(P<0.05)$, while there was no significant variation between the seasons in the abundance of the snails Biomphalaria alexandrina and Gabbiella senoriansis. 


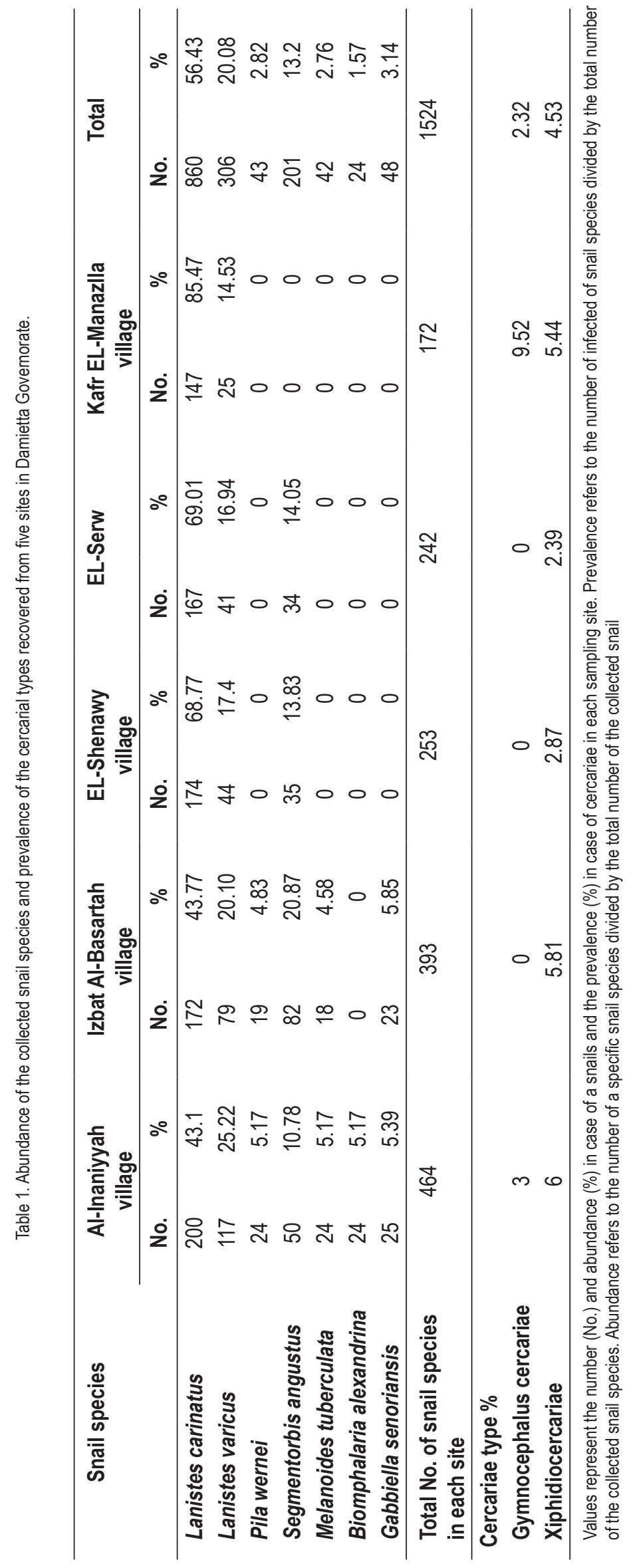




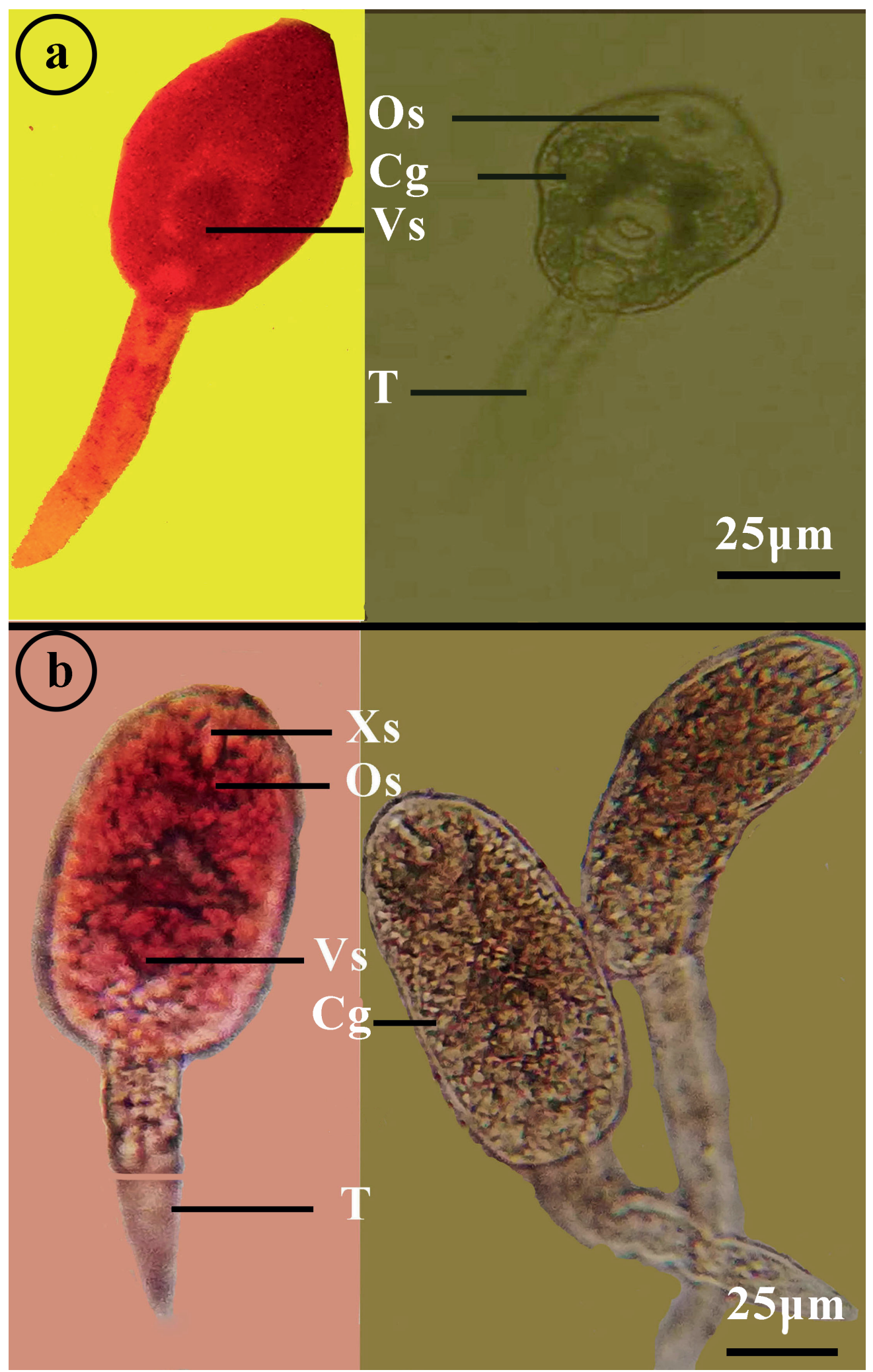

Fig. 3. Types of cercariae harvested from Lanistes carinatus collected from different sites in Damietta Governorate. a: Gymnocephalus cercariae; b: Xiphidiocercariae. Bo, Cercarial body; Cg, Cystogenous gland; Os, Oral sucker; T, Cercarial tail; Vs, Ventral sucker. (Scale bar: $25 \mu \mathrm{m}$ ) 
Table 2. Biodiversity indices of the freshwater snails collected from five sites in Damietta Governorate.

\begin{tabular}{|c|c|c|c|c|c|c|}
\hline Snail species & $\begin{array}{c}\text { Al-Inaniyyah } \\
\text { village }\end{array}$ & $\begin{array}{c}\text { Izbat Al-Basartah } \\
\text { village }\end{array}$ & $\begin{array}{c}\text { EL-Shenawy } \\
\text { village }\end{array}$ & EL-Serw & $\begin{array}{c}\text { Kafr EL-Manazlla } \\
\text { village }\end{array}$ & $\mathrm{P}$ - value \\
\hline Shannon - index (H) & $1.44 \pm 0.49$ & $1.21 \pm 0.27$ & $0.77 \pm 0.16$ & $1.04 \pm 0.71$ & $0.62 \pm 0.13$ & 0.086 \\
\hline Evenness - index (E) & $0.86 \pm 0.16$ & $0.78 \pm 0.36$ & $0.89 \pm 0.21$ & $1.1 \pm 0.56$ & $0.9 \pm 0.18$ & 0.002 \\
\hline
\end{tabular}

$P$ values were considered significant if $\leq 0.05$

The highest abundance of the snails Lanistes carinatus, Lanistes varicus, Biomphalaria alexandrina, and Gabbiella senoriansis was $7.28 \%, 2.80 \%, 0.25 \%$, and $0.60 \%$, respectively, during summer. While, the highest abundance of the snails Pila wernei and Segmentorbis angustus was $0.41 \%$ and $1.94 \%$, respectively, during winter, and the highest abundance of the snail Melanoides tuberculata was $0.33 \%$ during spring.

The gymnocephalus cercariae existed during spring, summer, and autumn. The highest prevalence of this cercarial type was recorded during spring $(4.05 \%)$, while the xiphidiocercariae existed during the four seasons. The highest prevalence of the xiphidiocercariae was recorded during summer $(9.57 \%)$. Statistical analysis revealed a significant difference between the different seasons in the prevalence of the xiphidiocercariae $(p \leq 0.001)$, while there was no significant variation between the different seasons in the prevalence of the gymnocephalus cercariae.

Fluctuation of water physicochemical parameters at the different snail collection sites

Table 4 summarizes the water physico-chemical parameters at the five sites under study. Generally, the water temperature and pH were almost similar among the five sites. Al-Inaniyyah village had the highest water TDS and EC (823.58 ppm and $1380 \mu \mathrm{S} /$ $\mathrm{cm}$, respectively). On the other hand, Kafr EL-Manazlla village had the lowest TDS and EC (385.5 ppm and $570 \mu \mathrm{S} / \mathrm{cm}$, respectively). Besides, this site had the highest DO $(7.02 \mathrm{mg} / \mathrm{L})$.

The relationship between water physicochemical parameters and snail abundance and cercariae prevalence

The relationship between the water physico-chemical parameters and the abundance of different snail species was analyzed by Pearson correlation test (table 5). The abundance of the snails Lanistes carinatus, Lanistes varicus, and Gabbiella senoriansis was positively correlated with water temperature with a high significance ( $p=0.00,0.00$ and 0.003 , respectively). The abundance of the snails Melanoides tuberculata and Biomphalaria alexandrina was positively correlated with water temperature $(p=0.346$, and 0.227 , respectively). However, the abundance of the snails Pila wernei and Segmentorbis angustus was negatively correlated with water temperature with a high significance $(p \leq 0.001)$. The prevalence of gymnocephalus cercariae and xiphidiocercariae was positively correlated with water temperature with a high significance for xiphidiocercariae $(p \leq 0.001)$.

The abundance of the snail Segmentorbis angustus was positively

Table 3. Seasonal changes in the abundance of snail species and the prevalence of cercaria types in Damietta Governorate.

\begin{tabular}{|c|c|c|c|c|c|}
\hline \multirow{3}{*}{ Snail species } & \multicolumn{4}{|c|}{ Seasons } & \multirow{3}{*}{ P- value } \\
\hline & Winter & Spring & Summer & Autumn & \\
\hline & $\% \pm S D$ & $\% \pm S D$ & $\% \pm S D$ & $\% \pm S D$ & \\
\hline Lanistes carinatus & $2.85 \pm 2.84$ & $4.90 \pm 2.23$ & $7.28 \pm 1.43$ & $5.20 \pm 1.81$ & 0.000 \\
\hline Lanistes varicus & $0.26 \pm 0.33$ & $1.56 \pm 0.71$ & $2.80 \pm 0.65$ & $1.55 \pm 0.93$ & 0.000 \\
\hline Pila wernei & $0.41 \pm 0.57$ & $0.04 \pm 0.16$ & $0.01 \pm 0.05$ & $0.18 \pm 0.3$ & 0.007 \\
\hline Segmentorbis angustus & $1.54 \pm 1.93$ & $1.02 \pm 2.02$ & 0 & 0 & 0.006 \\
\hline Melanoides tuberculata & 0 & $0.33 \pm 0.93$ & $0.22 \pm 0.62$ & 0 & 0.26 \\
\hline Biomphalaria alexandrina & 0 & $0.11 \pm 0.44$ & $0.25 \pm 0.62$ & 0 & 0.3 \\
\hline Gabbiella senoriansis & 0 & $0.21 \pm 0.46$ & $0.60 \pm 0.78$ & $0.04 \pm 0.16$ & 0.003 \\
\hline Cercariae type & $\% \pm S D$ & $\% \pm S D$ & $\% \pm S D$ & $\% \pm S D$ & P-value \\
\hline Gymnocephalus cercariae & 0 & $4.05 \pm 7.13$ & $3.76 \pm 9.24$ & $0.55 \pm 2.15$ & 0.14 \\
\hline Xiphidiocercariae & $1.5 \pm 3.98$ & $0.36 \pm 1.42$ & $9.57 \pm 7.66$ & $1.64 \pm 4.62$ & 0.00 \\
\hline
\end{tabular}

$\mathrm{SD}$, standard error; $\mathrm{P}$ values were considered significant if $\leq 0.05$ 


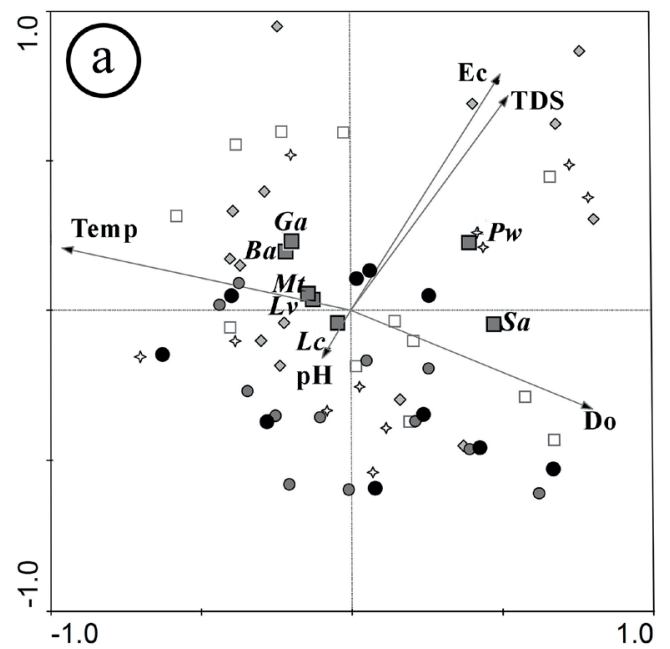

$\begin{array}{|ll|}\begin{array}{l}\text { Species } \\ \text { Sites }\end{array} & \rightarrow \text { Env. variables } \\ \diamond \text { Al-inaniyyah } & \square \text { Izbat Al-Basartah } \\ \diamond \text { EL-Serw } & 0 \text { Kafr EL-Manazlla }\end{array}$
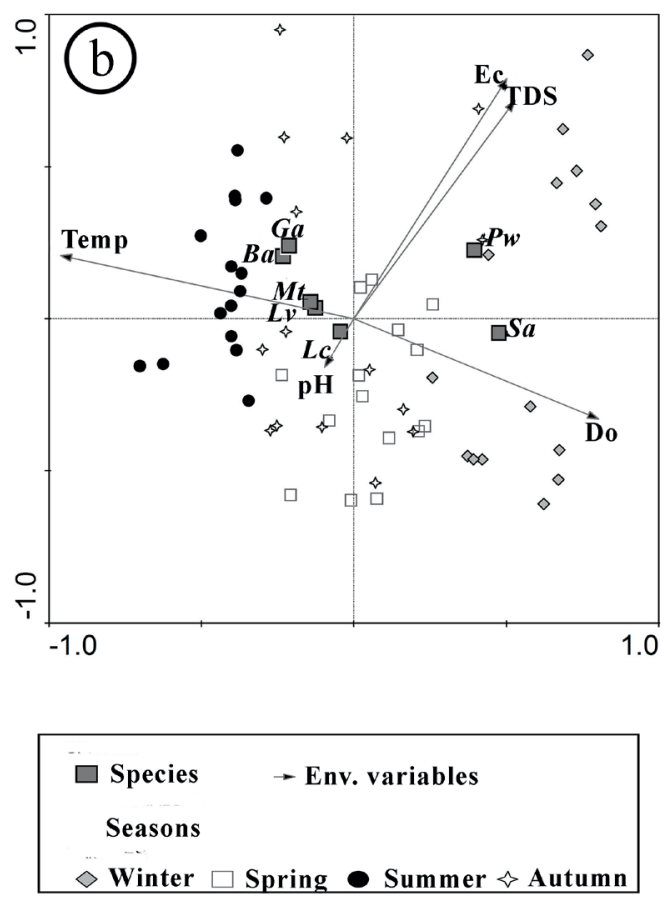

Fig. 4. Ordination diagram representing Canonical Correspondence Analysis of snail species and environmental variables in Damietta Governorate. a: Distribution of sampling sites and snail species along the gradients of environmental variables and $b$ : Seasonal changes and snail species distributed along the gradients of environmental variables. (Ba: Biomphalaria alexandrina; Do: Dissolved oxygen; Ec: Electrical conductivity; Ga: Gabbiella senoriansis; Lc: Lanistes carinatus; Lv: Lanistes varicus; Mt: Melanoides tuberculata; $\mathrm{pH}$; Water pH; Pw: Pila wernei; Sa: Segmentorbis angustus; Temp: Water temperature and TDS: Total dissolved salts).

correlated with DO with a high significance $(p=0.001)$. The abundance of the snail Pila wernei was positively correlated with DO with a high significance $(\mathrm{p}=0.01)$. The abundance of the snail Lanistes carinatus, Lanistes varicus, and Gabbiella senoriansis was negatively correlated with DO with a high significance $(p \leq 0.001)$. Also, the abundance of the snails Melanoides tuberculata and Biomphalaria alexandrina was negatively correlated with DO ( $p=0.572$ and 0.188 , respectively). The prevalence of gymnocephalus cercariae was positively correlated with $D o(p=0.267)$, while the prevalence of xiphidiocercariae was negatively correlated with Do with a high significance $(p \leq 0.001)$. The abundance of the snail Pila wernei was positively correlated with TDS with a high significance $(p \leq 0.001)$. However, the abundance of the snails Segmentorbis angustus, Biomphalaria alexandrina, and Gabbiella senoriansis was positively correlated with TDS ( $p=0.148,0.8$, and 0.83 , respectively). While, the abundance of the snails Lanistes carinatus was negatively correlated with TDS with a high significance $(\mathrm{p} \leq 0.001)$. Moreover, the abundance of the snails Lanistes varicus and Melanoides tuberculata was negatively correlated with $\operatorname{TDS}(p=0.57$, and 0.95 , respectively). The prevalence of gymnocephalus cercariae and xiphidiocercariae was negatively correlated with TDS $(p=0.4$ and 0.8 , respectively).

The abundance of the snail Pila wernei was positively correlated with water $\mathrm{EC}$ with a high significance $(\mathrm{p} \leq 0.001)$. The abundance of the snails Segmentorbis angustus and Biomphalaria alexandrina were positively but non-significantly correlated with water EC $(p=0.195$, and 0.575 , respectively). While, the abundance of the

Table 4. Variability of water physicochemical parameters among the sites of snail collection in Damietta Governorate.

\begin{tabular}{lccccc}
\hline \multicolumn{1}{c}{ Sites } & $\begin{array}{c}\text { Temp. } \\
{ }^{\circ} \mathrm{C}\end{array}$ & $\begin{array}{c}\text { Do. } \\
\mathrm{mg} / \mathrm{L}\end{array}$ & $\begin{array}{c}\text { TDS } \\
\text { Ppm }\end{array}$ & $\begin{array}{c}\text { EC } \\
\mu \text { S/cm }\end{array}$ & pH \\
\hline Al-Inaniyyah & $21.95 \pm 6.20$ & $6.74 \pm 0.95$ & $823.58 \pm 439.28$ & $1380 \pm 650$ & $7.59 \pm 0.30$ \\
Izbat Al-Basartah village & $22.08 \pm 6.52$ & $6.44 \pm 0.95$ & $669.75 \pm 368.12$ & $850 \pm 320$ & $7.47 \pm 0.29$ \\
EL-Shenawy village & $21.83 \pm 6.90$ & $6.61 \pm 0.92$ & $433.08 \pm 126.44$ & $640 \pm 180$ & $7.74 \pm 0.35$ \\
EL-Serw & $21.75 \pm 6.48$ & $6.66 \pm 1$ & $624.08 \pm 362.63$ & $920 \pm 530$ & $7.58 \pm 0.40$ \\
Kafr EL-Manazlla village & $22.29 \pm 6.01$ & $7.02 \pm 0.61$ & $385.50 \pm 88.93$ & $570 \pm 1300$ & $7.59 \pm 0.30$ \\
\hline
\end{tabular}


Table 5. Correlation analysis of the relationship between the physicochemical parameters of water and both of the snail abundance and cercaria prevalence in Damietta Governorate.

\begin{tabular}{|c|c|c|c|c|c|}
\hline Snail species & Temp. ${ }^{\circ} \mathrm{C}$ & $\begin{array}{l}\text { Do. } \\
\mathrm{mg} / \mathrm{L}\end{array}$ & TDS ppm & $\begin{array}{c}E C \\
\mu S / c m\end{array}$ & $\mathrm{pH}$ \\
\hline Lanistes carinatus & $\begin{array}{c}0.653^{* *} \\
(0.00)\end{array}$ & $\begin{array}{c}-0.587^{* *} \\
(0.00)\end{array}$ & $\begin{array}{c}-0.651^{* *} \\
(0.00)\end{array}$ & $\begin{array}{c}-0.428^{* *} \\
(0.001)\end{array}$ & $\begin{array}{l}-0.074 \\
(0.576)\end{array}$ \\
\hline Lanistes varicus & $\begin{array}{c}0.874^{* *} \\
(0.00)\end{array}$ & $\begin{array}{c}-0.715^{* *} \\
(0.00)\end{array}$ & $\begin{array}{l}-0.247 \\
(0.057)\end{array}$ & $\begin{array}{l}-0.155 \\
(0.236)\end{array}$ & $\begin{array}{l}-0.111 \\
(0.397)\end{array}$ \\
\hline Pila wernei & $\begin{array}{c}-0.415^{\star *} \\
(0.001)\end{array}$ & $\begin{array}{l}0.329^{*} \\
(0.01)\end{array}$ & $\begin{array}{c}0.454^{\star *} \\
(0.00)\end{array}$ & $\begin{array}{c}0.507^{* *} \\
(0.00)\end{array}$ & $\begin{array}{l}-0.125 \\
(0.343)\end{array}$ \\
\hline Segmentorbis angustus & $\begin{array}{c}-0.496^{* *} \\
(0.00)\end{array}$ & $\begin{array}{l}0.425^{* *} \\
(0.001)\end{array}$ & $\begin{array}{c}0.189 \\
(0.148)\end{array}$ & $\begin{array}{c}0.170 \\
(0.195)\end{array}$ & $\begin{array}{l}-0.043 \\
(0.747)\end{array}$ \\
\hline Melanoides tuberculata & $\begin{array}{c}0.124 \\
(0.346)\end{array}$ & $\begin{array}{l}-0.074 \\
(0.572)\end{array}$ & $\begin{array}{l}-0.008 \\
(0.95)\end{array}$ & $\begin{array}{l}-0.030 \\
(0.818)\end{array}$ & $\begin{array}{l}-0.057 \\
(0.665)\end{array}$ \\
\hline Biomphalaria alexandrina & $\begin{array}{c}0.158 \\
(0.227)\end{array}$ & $\begin{array}{l}-0.172 \\
(0.188)\end{array}$ & $\begin{array}{c}0.032 \\
(0.808)\end{array}$ & $\begin{array}{c}0.074 \\
(0.575)\end{array}$ & $\begin{array}{c}0.040 \\
(0.761)\end{array}$ \\
\hline Gabbiella senoriansis & $\begin{array}{l}0.383^{* *} \\
(0.003)\end{array}$ & $\begin{array}{c}-0.450^{* *} \\
(0.00)\end{array}$ & $\begin{array}{l}0.028 \\
(0.83)\end{array}$ & $\begin{array}{l}-0.071 \\
(0.588)\end{array}$ & $\begin{array}{l}-0.072 \\
(0.582)\end{array}$ \\
\hline \multicolumn{6}{|l|}{ Cercaria type } \\
\hline Gymnocephalus cercariae & $\begin{array}{c}0.203 \\
(0.119)\end{array}$ & $\begin{array}{c}0.146 \\
(0.267)\end{array}$ & $\begin{array}{c}-0.11 \\
(0.404)\end{array}$ & $\begin{array}{c}-0.112 \\
(0.395)\end{array}$ & $\begin{array}{c}0.080 \\
(0.542)\end{array}$ \\
\hline Xiphidiocercariae & $\begin{array}{c}0.494^{* *} \\
(0.00)\end{array}$ & $\begin{array}{c}-0.522^{* *} \\
(0.00)\end{array}$ & $\begin{array}{l}-0.031 \\
(0.813)\end{array}$ & $\begin{array}{l}-0.140 \\
(0.284)\end{array}$ & $\begin{array}{l}-0.121 \\
(0.356)\end{array}$ \\
\hline
\end{tabular}

$P$ values (between brackets) were considered significant if $\leq 0.05 ;{ }^{*},{ }^{* *}$ refer to high significance $(0.01$ and 0.001 , respectively)

snail Lanistes carinatus was negatively correlated with EC with a high significance $(\mathrm{p}=0.001)$. The abundance of the snails Lanistes varicus, Gabbiella senoriansis, and Melanoides tuberculata were negatively but non-significantly correlated with water $E C(p=0.236$, 0.588 , and 0.818 , respectively). The prevalence of gymnocephalus cercariae and xiphidiocercariae was negatively correlated with EC $(p=0.39$ and 0.28 , respectively).

The abundance of the snail Biomphalaria alexandrina was positively but non-significantly correlated with water $\mathrm{pH}(\mathrm{p}=0.76)$. While, the abundance of the snails Lanistes carinatus, Lanistes varicus, Pila wernei, Gabbiella senoriansis, Melanoides tuberculata, and Segmentorbis angustus was negatively correlated with water $\mathrm{pH}(\mathrm{p}>0.05)$. The prevalence of gymnocephalus cercariae was positively but non-significantly correlated with $\mathrm{pH}(\mathrm{p}=0.54)$, while the prevalence of xiphidiocercariae was negatively correlated with $\mathrm{pH}(\mathrm{p}=0.35)$.

Multivariate analysis of the snails distribution

The Canonical Correspondence Analysis (CCA) was performed to investigate the response of snail species to the environmental parameters (Fig. 4). The results indicate that the environmental parameters had significant influences on the snail species distribution ( $P=0.002$, F-ratio $=14.2$. . The Monte Carlo test revealed that only water temperature had a significant influence on the distribution of snail species (Table 6). According to CCA analysis, the abundance of Pila wernei and Segmentorbis angustus was associated with the lowest values of water temperature and the highest TDS, EC and DO concentrations. While, the abundance of Lanistes carinatus, Lanistes varicus, Biomphalaria alexandrina, Melanoides tuberculata, and Gabbiella senoriansis was associated with the highest value of water temperature and the lowest values of $\mathrm{pH}$ and $\mathrm{DO}$.

\section{Discussion}

In the present study, seven different freshwater snail species were identified and their distribution was evaluated at 5 different collection sites. The relation between the abundance of these snail species and the physico-chemical water quality was also studied. The Shannon diversity index status of the present investigation at 5 the study sites ranged from poor to bad status. The snails at Al-Inaniyyah and Izbat Al-Basartah villages were almost similarly distributed with high snail diversity and richness. While, the snails at EL-shenawy village, EL-Serw, and Kafr EL-Manazlla village 
Table 6. Monte Carlo test for evaluating the significance of environmental parameters in Damietta Governorate.

\begin{tabular}{lccc}
\hline Variables & Variance explained & F-ratio & P-value \\
\hline Temp. & 0.23 & 14.05 & 0.002 \\
Ec & 0.04 & 2.26 & 0.06 \\
pH & 0.01 & 0.73 & 0.596 \\
Do & 0 & 0.36 & 0.832 \\
TDS & 0.01 & 0.19 & 0.812 \\
\hline
\end{tabular}

$P$ values were considered significant if $\leq 0.05$

were distributed with low diversity and richness. The same results were also confirmed by the multivariate analysis (CCA). In a recent study, Mahmoud \& Sayed (2018) recorded 13 species of snails at 5 sites in Damietta governorate with a diversity Index $\left(\mathrm{H}^{\prime}\right)$ status ranging from poor to bad status. Although the study was conducted in the same governorate but at different study sites its results coincides with our data. This may give an indication of stable snail coexistence in the same ecosystem. According to Dung et al. (2010), Mohammed et al. (2016), and El-deeb et al. (2017), many factors affect the density and distribution of snail species. These factors include, but not limited to, the use of agriculture's chemicals, degree of pollutants, and the speed of the water that may be high during the initial period after an irrigation cycle.

Lanistes carinatus was the most predominant snail species in the study with $56.4 \%$ abundance. Consistent with this result, Lanistes carinatus was reported as the most abundant snail species at three Egyptian governorates; Giza, Damietta, and Minya (Mahmoud \& Sayed, 2018). Inconsistent with these reports, Hussein et al. (2011) found that the majority of the collected snails at El-Kelabia irrigation canal and the River Nile at Qena Governorate in the south of Egypt was of the species Cleopatra bulimoides (1704 specimens, $25.17 \%$ ). In Africa, Igbinosa et al. (2015) reported the abundance of the snail species Lanistes varicus, which constituted $44.6 \%$ of the collected snails at Ovia, Edo state in Nigeria. Outside Africa, Chantima et al. (2018) reported that about half of all snails collected from August 2016 to October 2017 in Mae Lao agricultural basin, Chiang Rai in Thailand, were of the species Bithynia siamensis (54.6\%).

In the current study, only two cercarial types (gymnocephalus cercariae and xiphidiocercariae) were detected in Lanistes carinatus at the 5 different study sites. The external features of the gymnocephalus cercaria in the present investigation were consistent with the characteristics of the gymnocephalus cercariae emerging from Bellamya aeruginosa (Xiao et al., 2005). The morphological features of the xiphidiocercariae in the current study were also consistent with the characteristics of the xiphidiocercaria harvested from Asolene platae (Dellagnola et al., 2019). Based on our results, only Lanistes carinatus was intermediate host for transmitting trematodes larvae at Damietta
Governorate. On the contrary of this, Yousif et al. (2010) recorded four main cercarial types (xiphidiocercariae, furcocercous cercariae, pleurolophocercous, and gymnocephalus cercariae) in the snail Melanoides tuberculata that was the most infected snail at the irrigation canal and the River Nile at Giza Governorate in Egypt. In the present study, the highest prevalence of cercariae was detected at the Nile's Damietta Branch in Kafr EL-Manazlla village, (4.53 \%). Similar to our results, Mohammed et al. (2016) reported xiphidiocercariae as the most common type of cercariae ( $44.3 \%$ ) but from the snail Bulinus truncates at the irrigation canal in the East Nile, Khartoum, Sudan. In addition, Mereta et al. (2019) reported the highest infection rate of xiphidiocercariae $(1.5 \%)$ emerging from Lymnaea natalensis at wet land of Omo-Gibe River Basin, southwest Ethiopia. According to Mereta et al. (2019), human activities such as open field defecation, urination, livestock grazing, farming, and swimming were highly correlated with trematode infection. Being industrial and agricultural governorate, it is unlikely that the latter factors only determine trematode prevalence and diversity in Damietta Governorate.

Our results showed that the prevalence of snail species varied during the four seasons. The highest snail abundance was recorded during summer while the lowest abundance was during winter. CCA analysis revealed that the density of the most snail species was high during summer and spring except Pila wernei, which was high during winter. The feeding habits of each snail species could affect its seasonal occurrence. The higher density of snails recorded in the dry season was thought to be due to the occurrence of microflora (food supply) and aquatic macrophytes (Salawu \& Odaibo 2014). According to Kazibwe et al. (2006) and Oloyede et al. (2017), some freshwater snails are herbivores and more abundant during the late rainy seasons due to increase in light intensity and hence, the increased photosynthesis and the more abundance of the aquatic macrophytes. Similar to our results, Igbinosa et al. (2015) recorded an increase in the abundance of Lanistes varicus from August to September at Ovia, Edo state, Nigeria. These authors believed that the feeding habits and light are important factors in the seasonal fluctuations of the snail prevalence. Based on a study in the south of Egypt, Hussein et al. (2011) reported varied snail densities during the different 
seasons, with the highest seasonal peak recorded during autumn while the lowest was during winter. It is noteworthy to report the considerable increase in the temperature in the south of Egypt compared to the north. According to Hussein et al. (2011), Lanistes carinatus showed a maximum reproduction during summer, the highest number of Gabbiella senaariensis was recorded during winter, while Biomphalaria alexandrina showed March - May peak and reached the highest number in April. Our findings are in consistence with the report of Marie et al. (2015) that the snails Biomphalaria alexandrina and Lanistes carinatus showed the highest peak in spring at four northern Egyptian governorates; Giza, Ismailia, Menoufia, and Gharbia. Pointier et al. (1993) recorded a maximum reproduction of Melanoides tuberculata between June and November. Beyond the feeding habits, Islam et al. (2015) reported that late summer provides an optimum temperature for the breeding and reproduction of snails. According to our results the gymnocephalus cercariae disappeared during winter and the highest prevalence of these cercariae was recorded during spring. While, the xiphidiocercariae were detected during the four seasons with the highest prevalence was during summer. The effect of climatic changes on trematode occurrence has been documented in several studies. Islam et al. (2015) revealed that the prevalence of the gymnocephalus cercariae emerging from Lymnaea sp. varied significantly with seasonal changes and reached a peak in April - October then decreased in February - March, and disappeared in November - January. The higher abundance of snails during summer, as recorded in the current study, and dry seasons in general might lead to increased cercarial prevalence as it will be easier for the miriacidia to find new snails for infection. The mean value of water temperature in the current study was slightly similar between the 5 sites and ranged from $21.75-22.29^{\circ} \mathrm{C}$. This temperature is thought to be suitable for increasing the population density of snails and the emergence of cercariae from snails. According to Yirenya-Tawiah et al. (2011), the temperature ranging from $27.4-33^{\circ} \mathrm{C}$ is suitable for the survival of snails. Marie et al. (2015) revealed that the mean values of water temperature ranged from $23.5-25.7^{\circ} \mathrm{C}$ at seven sites in the four northern Egyptian governorates; Giza, Ismailia, Menoufia, and Gharbia. The highest occurrence of the snail Biomphalaria alexandrina was recorded at $28^{\circ} \mathrm{C}$ and $31^{\circ} \mathrm{C}$ in two northern Egyptian governorates; Giza and Kafr El Shiekh (El-deeb et al., 2017). Salawu \& Odaibo (2014) reported the suitability of the water temperature range $21.7-29^{\circ} \mathrm{C}$ in all river bodies at Ogun state, Nigeria, for the survival of aquatic snail species. Islam et al. (2015) revealed that the suitable water temperature needed for the development of gymnocephalus cercariae in Lymnaea sp. was $18-34^{\circ} \mathrm{C}$, while Mohammed et al. (2016) suggested that the proper mean value of water temperature needed for the development of xiphidiocercariae in Lymnaea natalensis and Bulinus truncatus was $16-28^{\circ} \mathrm{C}$. The distribution of most snail species (except Pila wernei and Segmentorbis angustus) and the two types of cercariae in the current study were positively correlated with water temperature. Our findings are consistence with Hussein et al. (2011) study, which revealed a positive correlation between water temperature and the abundance of Lanistes carinatus, Melanoides tuberculata, and Biomphalaria alexandrina.For the snails Segmentorbis angustus, Salawu \& Odaibo (2014) observed a negative correlation between the water temperature and the abundance of the snail. Sunita et al. (2012) reported a direct correlation between the prevalence of gymnocephalus cercariae emerging from Lymnaea snails were and the water temperature. Also, Mohammed et al. (2016) reported a direct correlation between the distribution of xiphidiocercariae emerging from Lymnaea natalensis and Bulinus truncatus and water temperature. In addition to its influence on the abundance of aquatic snails, water temperature is thought to influence the rate of parasite development in the snail host, and probably the distribution of the related disease (McCreesh \& Booth 2014).

In the current study, the mean value of water dissolved oxygen ranged from $6.44-7.02 \mathrm{mg} / \mathrm{l}$. Several reports have addressed the importance of a suitable range of oxygen concentration for the snail activity, feeding, and reproduction. Salawu \& Odaibo (2014) recorded mean dissolved oxygen of $6.1 \pm 4.6 \mathrm{mg} / \mathrm{L}$ at Ogun state, Nigeria. According to our results, the distribution of most snails, except Pila wernei and Segmentorbis angustus, were negatively correlated with the value of dissolved oxygen. These results are supported by Hussein et al. (2011) who revealed that the water DO was negatively correlated with the abundance of Lanistes carinatus, Melanoides tuberculata, and Gabbiella senoriansis, and that DO was positively correlated with the abundance of Biomphalaria alexandrina. According to Sharma (1986), some snails could survive in very low oxygen conditions. However, Ofoezie (1999) reported that the density of some pulmonate snails, e.g. Bulinus sp. and Lymnaea natalensis, increased with the increase in DO value. Our results showed a positive correlation between the distribution of gymnocephalus cercariae and the value of $\mathrm{DO}$, while xiphidiocercariae distribution was negatively correlated with DO. Similar to our results, Mereta et al. (2019) reported a negative correlation between the prevalence of the xiphidiocercariae emerging from Lymnaea natalensis and water DO. However, Sunita et al. (2012) recorded a negative correlation between the prevalence of gymnocephalus cercariae and water DO ranging $(1-6.02 \mathrm{mg} / \mathrm{l})$. This discrepancy could be due to the difference in concentration and range; in the study of Sunita et al. (2012) the DO ranged from 1 to $6.02 \mathrm{mg} / \mathrm{L}$

According to our results the mean values of TDS and EC of the collected water samples ranged from $385.5-823.58 \mathrm{ppm}$ and $570-1380 \mu \mathrm{S} / \mathrm{cm}$, respectively. Close to our results, Marie et al. (2015) revealed that the values of TDS and EC ranged from $369.5-1221 \mathrm{ppm}$ and $530-2155 \mu \mathrm{S} / \mathrm{cm}$, respectively, at eight sites in the northern Egyptian governorates Giza, Ismailia, Menoufia, and Gharbia. However, Hussein et al. (2011) indicated that the values of TDS and EC ranged from $145-638 \mathrm{ppm}$ and $240-930 \mu \mathrm{S} / \mathrm{cm}$, respectively, at six sites in Qena Governorate in the south of Egypt. The latter values reflect the different nature 
of water at the southern governorates (e.g. Qena) in Egypt, where the river Nile starts its journey in Egypt and the water quality is considerably different. Rowel et al. (2015) observed that the values of TDS and EC ranging from $58-568 \mathrm{ppm}$ and $112-1081$ $\mu \mathrm{S} / \mathrm{cm}$, respectively, are suitable for the survival of Biomphalaria at six locations in Ugandan shores of Lake Albert and Lake Victoria. Yirenya-Tawiah et al. (2011) revealed that a total EC range from $70-122 \mu \mathrm{S} / \mathrm{cm}$ is suitable for the survival of the snail intermediate host for schistosomiasis. Based on our results, the distribution of most snail species Lanistes carinatus, Lanistes varicus, and Melanoides tuberculata was negatively correlated with the mean values of TDS and EC. These snail types might be detected at a wide range of water TDS and EC. Similar to our findings, Yigezu et al. (2018) observed an association of the distribution of snail species with the highest EC values. Hussein et al. (2011) observed a negative correlation between the abundance of Lanistes carinatus, Gabbiella senaariensis, Melanoides tuberculata, and Biomphalaria alexandrina and TDS and EC. Also, Salawu \& Odaibo (2014) observed a negative correlation between the abundance of Lanistes lybicus and Melanoides tuberculata and TDS and EC. Moreover, Rowel et al. (2015) and Marie et al. (2015) detected a negative correlation between the abundance of Biomphalaria alexandrina and $\mathrm{EC}$ and suggested that this snail species might have a limit range of water conductivity permitting it to live whatever in the flowing or stagnant water. The distribution of gymnocephalus cercariae and xiphidiocercariae was negatively correlated with the values of TDS and EC. Similarly, Mereta et al. (2019) revealed that the prevalence of the xiphidiocercariae emerging from Lymnaea natalensis was negatively correlated with water conductivity and were detected at $159 \mu \mathrm{S} / \mathrm{cm}$, while echinostome cercariae were found at $181 \mu \mathrm{S} / \mathrm{cm}$ of water conductivity.

The mean value of $\mathrm{pH}$ in the current study ranged from $7.47-7.74$. This range is slightly alkaline and might be suitable for the existence of the different snail and cercariae species. El-deeb et al. (2017) revealed that Biomphalaria alexandrina survived in almost the same range of water $\mathrm{pH} 7.22-7.33$ in the two northern Egyptian governorates Giza and Kafr El Shiekh. Hussein et al. (2011) recorded $\mathrm{pH}$ values ranging from $6.4-7.9$ at six sites in Qena Governorate in the south of Egypt. In addition, Opisa et al. (2011) found that snails survive at a wide range of water $\mathrm{pH}(6.7$ - 11). In the present study, the abundance of most snail species was negatively correlated with $\mathrm{pH}$ except Biomphalaria alexandrina. Our findings are in consistence with Hussein et al. (2011) who reported a negative correlation between the water $\mathrm{pH}$ and the abundance of Lanistes carinatus, Gabbiella senaariensis, and Biomphalaria alexandrina. Marie et al. (2015) recorded a negative correlation between the abundance of Biomphalaria alexandrina and pH levels. Salawu \& Odaibo (2014) reported positive correlation between the water $\mathrm{pH}$ and the abundance of the snail Segmentorbis angustus. Opisa et al. (2011) and Salawu \& Odaibo (2014) suggested that snail abundance is independent of water $\mathrm{pH}$ value fluctuations. Because of the conflicting reports, it seems that the effect of water $\mathrm{pH}$ on snail abundance is limited. Our results showed that the distribution of gymnocephalus cercariae is positively correlated with water $\mathrm{pH}$, while the xiphidiocercariae distribution is negatively correlated with water $\mathrm{pH}$. Sunita et al. (2012), Yigezu et al. (2018), and Mereta et al. (2019) reported a direct correlation between the prevalence of both of echinostome cercariae and xiphidiocercariae and the $\mathrm{pH}$. It worthy to report that, the $\mathrm{pH}$ ranges in all sites of the current study were very close and the range was very narrow $(7.47-7.74)$.

According to the current results, only two types of trematode cercariae; gymnocephalus cercariae and xiphidiocercariae, were harvested from the same snail, Lanistes carinatus and the total prevalence of xiphidiocercariae was higher than that of gymnocephalus cercariae. The relatively low prevalence of gymnocephalus cercariae that emerged from this snail may be due to the antagonism by xiphidiocercariae. Mohammed et al. (2016) suggested that the low prevalence of furcocercous cercariae emerging from Bulinus truncates could be due to antagonism by xiphidiocercariae, which were found with high rates. Antagonism involves complex interactions amongst larval trematode species and it has predictable outcomes that can influence patterns of abundance among these species. Interspecific competition for resources and space represents a potentially strong selection pressure for trematodes infecting snail hosts (Hechinger et al., 2011). Laidemitt et al. (2019) observed an obligatory dependence of some digenetic trematode species on Biomphalaria snails for their larval development and they reported that the larval stages of these species might strongly interact with the larvae of Schistosoma mansoni for access to the resources offered by these snails. There is a possibility that xiphidiocercariae in the current study might be competed with other trematode larvae (gymnocephalus cercariae) for infecting Lanistes carinatus. The definitive hosts for xiphidiocercariae and gymnocephalus cercariae are different (Insectivorous bats and fish-eating birds or mammals, respectively) and, also, the secondary intermediate hosts for these two cercarial types are different (Damson or dragon fly nymphs and fish, respectively). Although it is unlikely, it is possible that the difference in the existence and abundance of these hosts could affect the life cycle and the natural occurrence of xiphidiocercariae and gymnocephalus cercariae.

According to our findings, the apple snails Lanistes carinatus and Lanistes varicus were detected at the 5 studied sites in Damietta governorate. Although, these snails might act as pests for agriculture fields, they may serve as medically and ecologically important factors by consuming aquatic weeds and reducing schistosomiasis. Anto et al. (2005) reported that Lanistes varicus has the ability to control the intermediate host snail of intestinal schistosomiasis. Also, Anto \& Bimi (2017) revealed that Lanistes varicus snail feeds on the egg masses and juveniles of Bulius truncatus snails. Our findings, therefore, suggest that the invasion of some Ampularidae freshwater snails (Lanistes carinatus and Lanistes varicus) in Damietta governorate may be the cause of 
the low abundance of Biomphalaria alexandrina and the absence of Bulinus and Lymnaea genera, which were not detected at all in the current study in spite of the extensive search. The invasion of Lanistes carinatus by xiphidiocercariae in Damietta governorate might be the cause of the low infection of this snail with gymnocephalus cercariae, and the absence of Schistosoma larval stages at all sites in the present investigation.

To conclude, the abundance of snail species varied between the five locations in Damietta governorate and was correlated positively or negatively with some physico-chemical parameters. The invasion of the freshwater snails Lanistes carinatus and Lanistes varicus in Damietta governorate may be the cause of the low abundance of Schistosoma intermediate hosts. The invasion of Lanistes carinatus by xiphidiocercariae may be the cause of the low prevalence of gymnocephalus cercariae and the complete absence of Schistosoma larval stages at all the studied sites. Our study recommends further characterization of the snail distribution and the snail interrelationships and suggests a controlled use of the Ampularidae freshwater snails in the biological control of parasite intermediate hosts.

\section{Conflict of interest}

The authors declare no conflict of interest.

\section{Acknowledgement}

The authors are thankful to Dr. Wael S. El-Tohamy, Zoology Department in our institute, for the help with the statistical analysis.

\section{References}

Anto, F., BIMI, L. (2017): Potential of Lanistes varicus in limiting the population of Bulinus truncatus. BMC Res Notes, 10(1): 509. DOI: 10.1186/s13104-017-2837-9

Anto, F., Bosompem, K., KpikPI, J., AdjuIK, M., Edoh, D. (2005): Experimental control of Biomphalaria pfeifferi, the intermediate host of Schistosoma mansoni, by the ampullariid snail Lanistes varicus. Ann Trop Med Parasitol, 99 (2): 203 - 209. DOI: 10.1179/136485905X17425

BadR, E. S., El-SonbatI, M., NASSef, H. (2013): Water quality assessment in the Nile River, Damietta branch, Egypt. Int. J. Environ. Sci., 8(1): 41 - 50

BDIR, S., AdwAN, G. (2011): Larval stages of digenetic trematodes in Melanopsis praemorsa snails from freshwater bodies in Palestine. Asian Pac J Trop Biomed., 1(3): 200 - 204. DOI: 10.1016/S22211691(11)60027-0

Besprozvannykh, V., Ngo, H., Ha, N., Hung, N., Rozhrovan, K., ERmolenko, A. (2013): Descriptions of digenean parasites from three snail species, Bithynia fuchsiana (Morelet), Parafossarulus striatulus Benson and Melanoides tuberculata Müller, in North Vietnam. Helminthologia, 50(3): 190 - 204. DOI: 10.2478/s11687-

\section{3-0131-5}

BRown, D. (1994): Fresh Water Snails of Africa and Their Medical Importance. $2^{\text {nd }}$ Edition, Oxfordshire, UK, Taylor \& Francis, 678 pp. Chantima, K., Suk-Ueng, K., Kampan, M. (2018): Freshwater Snail Diversity in Mae Lao Agricultural Basin (Chiang Rai, Thailand) with a Focus on Larval Trematode Infections. Korean J Parasitol., 56(3): 247 - 257. DOI: 10.3347/kjp.2018.56.3.247

Chen, F., Chen, S. R., LI, K. R., LI, T. H., Fang, W., Luo, J. J. (2011): Investigation on outbreak of Angiostrongyliasis cantonensis due to consumption of snail food in Dali City. Zhongguo Xue Xi Chong Bing Fang Zhi Za Zhi, 23(6): 687 - 690

Dellagnola, F. A., Montes, M. M., Martorelli, S. R., Vega, I. A. (2019): Morphological characterization and molecular phylogeny of zoonotic trematodes in the freshwater snail Asolene platae. Parasitology, 146 (7): 839 - 848. DOI: 10.1017/ S0031182019000027

Dida, G. O., Gelder, F. B., Anyona, D. N., Matano, A. S., Abuom, P. O., AdokA, S. O., Ofulla, A. V. (2014): Distribution and abundance of schistosomiasis and fascioliasis host snails along the Mara River in Kenya and Tanzania. Infect Ecol Epidemiol., 4(1):1 - 7. DOI: 10.3402/iee.v4.24281

Dung, B. T., Madsen, H., The, D. T. (2010): Distribution of freshwater snails in family-based VAC ponds and associated waterbodies with special reference to intermediate hosts of fish-borne zoonotic trematodes in Nam Dinh Province, Vietnam. Acta Trop, 116(1): 15 - 23. DOI: 10.1016/j.actatropica.2010.04.016

El-Amier, Y. A., Zahran, M. A., Al-Mamoorl, S. O. (2015): Environmental changes along Damietta branch of the River Nile, Egypt. J. Environ. Sci. Mansoura Univ., 44(1): 235 - 255

El-deeb, F. A. A., El-Shenawy, N. S., Soliman, M. F. M., Mansour, S. A. (2017): Freshwater snail distribution related to physicochemical parameters and aquatic macrophytes in Giza and Kafr El-Shiekh Governorates, Egypt. Int J Vet Sci Res, 3(1): 8-13. DOI: 10.17352/ ijvsr.000015

ELDER, J. F., ColLINS, J. J. (1991): Freshwater molluscs as indicators of bioavailability and toxicity of metals in surface-water systems. Rev Environ Contam Toxicol, 122: 37 - 79. DOI: 10.1007/978-14612-3198-1_2

ELSHEIKHA, H. M., ELSHAZLY, A. M. (2008): Host-dependent variations in the seasonal prevalence and intensity of heterophyid encysted metacercariae (Digenea: Heterophyidea) in brackish water fish in Egypt. Vet Parasitol, 153(1-2): 65 - 72. DOI: 10.1016/j. vetpar.2008.01.026

GREENE, S. D. (2008): Extending integrated pest management to the golden apple snail: examining a community centre approach in northeast Thailand. Int J Pest Manag, 54(2): 95 - 102. DOI: 10.1080/09670870701621282

HECHINGER RF, WOOD AC, KURIS AM. (2011): Social organization in a flatworm: trematode parasites form soldier and reproductive castes. Proc. Biol. Sci., 278 (1706): 656 - 665. DOI: 10.1098/ rspb.2010.1753

Hossain, R. A.; Pramanik, M. H., Hasan, M. (2017): Diversity indices 
of plankton communities in the River Meghna of Bangladesh. Int. J. Fish. Aquat. Stud., 5(3): $330-334$

Hussein, M. A., Obuid-Allah, A. H., Mahmoud, A. A., Fangary, H. M. (2011): Population dynamics of freshwater snails (Mollusca: Gastropoda) at Qena Governorate, upper Egypt. Egypt Acad J Biol Sci C Physiol Mol Biol., B. Zoology, 3(1): 11 - 22. DOI: 10.21608/ EAJBSZ.2011.14309

IgBinosa, B. I., Izegaegbe, J. I., Okafor, F. C., Uhunwangho, D. A. (2015): Ecological survey of freshwater ecosystems of Ovia, Edo state Nigeria for gastropod molluscs. Anim. Res. Int., 12(2): $2171-2177$.

Islam, K. M., Islam, M. D., Rauf, S. M. A., Khan, A., Hossain, M. K., Sarkar, S., Rahman, M. (2015): Effects of climatic factors on prevalence of developmental stages of Fasciola gigantica infection in Lymnaea snails (Lymnaea auricularia var rufescens) in Bangladesh. Arch Razi Inst., 70(3): 187 - 194. DOI: 10.7508/ ari.2015.03.007

Joshi, R. C., Delacruz, M. S., Martin, E. C., Cabigat, J. C., Bahatan, R. G., Bahatan, A. D., Cayong, A. B. (2001): Current status of the golden apple snail in the Ifugao rice terraces, Philippines. J. Sustain. Agric., 18(2-3): 71 - 90. DOI: 10.1300/J064v18n02_07

Kazibwe, F., Makanga, B., Rubaire-Akilki, C., Ouma, J., Kariuki, C., KabATEREINE, N. B., StothARD, J. R. (2006): Ecology of Biomphalaria (Gastropoda: Planorbidae) in Lake Albert, Western Uganda: snail distributions, infection with schistosomes and temporal associations with environmental dynamics. Hydrobiologia, 568(1): 433 - 444. DOI: 10.1007/s10750-006-0224-y

Laidemitt, M.R., Anderson, L.C., Wearing, H.J., Mutuku, M.W., MkoJI, G.M., LOKER, E.S. (2019). Antagonism between parasites within snail hosts impacts the transmission of human schistosomiasis. Elife: 8(1), 1 - 17. DOI: 10.7554/eLife.50095

LotFY, W. M., LotFY, L. M. (2015): Synopsis of the Egyptian freshwater snail fauna. Folia Malacol, 23(1): 19 - 40. DOl: 10.12657/folmal.023.002

LUHE, M. (1909): Parasitische Plattwurmer. I. Trematodes. Die Susswasser fauna Deutschlands. [Parasitic flatworms. I. Trematodes. The freshwater fauna of Germany.],17: 12 - 17 (In German)

Madsen, H., Hung, N. M. (2014): An overview of freshwater snails in Asia with main focus on Vietnam. Acta Trop, 140: 105 - 117. DOI: 10.1016/j.actatropica.2014.08.005

Mahmoud, K., Sayed, S. S. (2018): Association pattern among different snails and other macroinvertebrate species at certain freshwater courses in Egypt. Egypt J Aquat Biol Fish, 22(3): 99 - 110. DOI: 10.21608/EJABF.2018.8934

Marie, M. A. S., El-Deeb, F. A. A., Hasheesh, W. S., Mohamed, R. A., SAYED, S. S. M. (2015): Impact of seasonal water quality and trophic levels on the distribution of various freshwater snails in four Egyptian governorates. Appl Ecol Environ Sci, 3(4): 117 - 126. DOI: 10.12691/aees.3.4.4

McCREESH N, Booth M (2014) The effect of increasing water temperatures on Schistosoma mansoni transmission and
Biomphalaria pfeifferi population dynamics: an agent-based modelling study. PLOS ONE, 9(7): e101462. DOI: 10.1371/journal. pone. 0101462

Mereta, S. T., Bedewi, J., Yewhalaw, D., Mandefro, B., Abdie, Y., TEGEGNE, D., KLoos, H. (2019): Environmental determinants of distribution of freshwater snails and trematode infection in the Omo Gibe River Basin, southwest Ethiopia. Infect Dis Poverty, 8(1), 93. DOI: 10.1186/s40249-019-0604-y

Mohammed, N. A., Madsen, H., Ahmed, A. A. A. (2016): Types of trematodes infecting freshwater snails found in irrigation canals in the East Nile locality, Khartoum, Sudan. Infect Dis Poverty, 5(1): 16. DOI: 10.1186/s40249-016-0108-y

OfoeZIE, I. E. (1999): Distribution of freshwater snails in the manmade Oyan Reservoir, Ogun State, Nigeria. Hydrobiologia., 416: 181 - 191. DOI: 10.1023/A:1003875706638

Okafor, F. C., Ngang, I. (2004): Freshwater snails of Niger-Cem, Nkalagu eastern Nigeria: Observations on some demographic aspects of the schistosome-transmitting bulinids. Anim. Res. Int., 1(2): 120 - 124. DOI: 10.4314/ari.v1i2.40754

Oloyede, O. O., Otarigho, B., MorenikeJl, O. (2017): Diversity, distribution and abundance of freshwater snails in Eleyele dam, Ibadan, south-west Nigeria. Zool Ecol, 27(1): 35 - 43. DOI: 10.1080/21658005.2016.1245934

Opisa, S., Odiere, M. R., Jura, W. G., Karanja, D. M., Mwinzi, P. N. (2011): Malacological survey and geographical distribution of vector snails for schistosomiasis within informal settlements of Kisumu City, western Kenya. Parasit Vectors, 4(1): 226. DOI: 10.1186/1756-3305-4-226

Pinto, H.A., Cantanhede, S.P.D., Thiengo, S.C., de Melo, A.L. Fernandez, M.A. (2015): The apple snail Pomacea maculata (caenogastropoda: Ampullariidae) as the intermediate host of Stomylotrema gratiosus (trematoda: Stomylotrematidae) in Brazil: The first report of a mollusc host of a stomylotrematid trematode. $J$ Parasitol, 101(2): 134 - 139. DOI: 10.1645/14-659.1

Pointier, J. P., Jourdane, J. (2000): Biological control of the snail hosts of schistosomiasis in areas of low transmission: the example of the Caribbean area. Acta Trop, 77(1): 53 -60. DOI: 10.1016/ S0001-706X(00)00123-6

Pointier, J. P., Théron, A., Borel, G. (1993): Ecology of the introduced snail Melanoides tuberculata (Gastropoda: Thiaridae) in relation to Biomphalaria glabrata in the marshy forest zone of Guadeloupe, French West Indies. J Molluscan Stud, 59(4): 421 - 428. DOI: $10.1093 / \mathrm{mollus} / 59.4 .421$

Rollinson, D., Stothard, J. R., Southgate, V. R. (2001): Interactions between intermediate snail hosts of the genus Bulinus and schistosomes of the Schistosoma haematobium group. Parasitology, 123(7): 245 - 260. DOI: 10.1017/ S0031182001008046

Rowel, C., Fred, B., Betson, M., Sousa-Figueiredo, J. C., Kabatereine, N. B., StOthARD, J. R. (2015): Environmental epidemiology of intestinal schistosomiasis in Uganda: population dynamics of Biomphalaria (Gastropoda: Planorbidae) in Lake Albert and Lake 
Victoria with observations on natural infections with digenetic trematodes. Biomed Res Int., 2015: DOI: 10.1155/2015/717261

RozendAAL, J. A. (1997): Vector control: methods for use by individuals and communities. Geneva, Switzerland, WHO, 424 pp. Salawu, O. T., Odaibo, A. B. (2014): The bionomics and diversity of freshwater snails species in Yewa North, Ogun State, Southwestern Nigeria. Helminthologia, 51(4): 337 - 344. DOI: 10.2478/s11687014-0250-7

SUNITA, K., KUMAR, P., Singh, D. K. (2012): Abiotic environmental factors and infection of Fasciola gigantica in vector snail Lymnaea acuminata. Researcher, 4(8): $49-53$

Sharma, K. K., Bangotra, K., SainI, M. (2013): Diversity and distribution of Mollusca in relation to the physico-chemical profile of Gho-Manhasan stream, Jammu (J \& K). Int J Biodivers Conserv, 5(4): 240 - 249. DOI: $10.5897 / / J B C 12.127$

SHARMA, R. C. (1986): Effect of physico-chemical factors on benthic fauna of Bhagirathi River, Garhwal Himalaya. Indian J. Ecol., 13(1): $133-137$

Tesana, S., Srisawangwong, T., Sithithaworn, P., Laha, T. (2008): Angiostrongylus cantonensis: experimental study on the susceptibility of apple snails, Pomacea canaliculata compared to Pila polita. Exp Parasitol., 118(4): 531 - 535. DOI: 10.1016/j. exppara.2007.11.007
Ukam, U. A., Odey, A. R., Paul, J. A., Akpang, I. E., Patrick, U. I. (2018): Influence of Water Quality on the Abundance of Freshwater Mollusc in Biase, Cross River State, South-Eastern Nigeria. Adv Res., 15(2):1 - 12. DOI: 10.9734/AIR/2018/41705

XiAO, X., WANG, T., Zheng, X., Shen, G. AND TIAn, Z. (2005): In vivo and in vitro encystment of Echinochasmus liliputanus cercariae and biological activity of the metacercariae. J. Parasitol., 91(3): 492 - 498. DOI: 10.1645/GE-445R

Yigezu, G., Mandefro, B., Mengesha, Y., Yewhalaw, D., Beyene, A., AHMEDNUR, M., MERETA, S. T. (2018): Habitat suitability modelling for predicting potential habitats of freshwater snail intermediate hosts in Omo-Gibe river basin, Southwest Ethiopia. Ecol Inform., 45: 70 - 80. DOI: 10.1016/j.ecoinf.2018.04.002

Yirenya-Tawiah, D. R., Rashid, A. A., Futagbi, G., Aboagye, I., Dade, M. (2011): Prevalence of snail vectors of schistosomiasis in the Kpong Head Pond, Ghana. West African J. Appl. Ecol., 18(1): 39 - 45. DOI: 10.4314/wajae.v18i1.70310

Yousif, F., Ibrahim, A., El Bardicy, S., Sleem, S., Ayoub, M. (2010): Morphology of new eleven cercariae procured from Melanoides tuberculata snails in Egypt. Aust J Basic Appl Sci., 4(6): $1482-1494$ 